\title{
Poets as Judges: Judicial Rhetoric and the Literary Imagination
}

\author{
Martha C. Nussbaum $\dagger$
}

I read something that moved me a lot not very long ago. I was reading something by Chesterton, and he was talking about one of the Brontes, ... or Jane Eyre that she wrote. He said if you want to know what that is like, you go and you look out at the city-I think he was looking at London-and he said, you know, you see all those houses now, even at the end of the 19th century, and they look all as if they're the same. And you think all of those people are out there, going to work, and they're all the same. But, he says, what Bronte tells you is they are not the same. Each one of those persons and each one of those houses and each one of those families is different, and they each have a story to tell. Each of those stories involves something about human passion. Each of those stories involves a man, a woman, children, families, work, lives. And you get that sense out of the book.

So sometimes I have found literature very helpful as a way out of the tower. ${ }^{1}$

Stephen G. Breyer

I. THE ARBITER OF THE DIVERSE

In 1867, standing "by blue Ontario's shore," Walt Whitman "mused of these warlike days and of peace return'd, and the dead

$\dagger$ Professor of Law and Ethics, The University of Chicago. This essay is a version of the final chapter of Poetic Justice: The Literary Imagination in Public Life (Beacon, forthcoming 1996). As such it is preceded by fuller discussions of both imagination and emotion, especially in connection with an interpretation of Dickens's Hard Times, which provides occasions to contrast the literary with the economic use of the imagination. I shall try to indicate here the most important conclusions of those discussions. I am grateful to Richard A. Posner and Cass R. Sunstein for their helpful comments on an earlier draft.

1 Confirmation Hearings for Stephen G. Breyer to be an Associate Justice of the United States Supreme Court, Senate Committee on the Judiciary, 103d Cong, 2d Sess 89 (July 13, 1994) (Miller Reporting transcript). 
that return no more." And, as he mused, a "Phantom gigantic superb, with stern visage, accosted" him, ${ }^{3}$ demanding poets for the public life of America. ${ }^{4}$ This Phantom-the fused presence, I think, of the young war dead and their dead President-claims that only poets are fully equipped to embody the norms of judgment that will hold these States together as a nation. "Their Presidents," comments the Phantom, "shall not be their common referee so much as their poets shall."

The Phantom goes on to describe the poet as a sort of judge. ${ }^{6}$ This poet-judge embodies a very particular norm of judgment, one that sets him at odds with some conventional models of judging. Here is part of the Phantom's normative description:

Of these States the poet is the equable man,

Not in him but off from him things are grotesque, eccentric, fail of their full returns, ... .

He bestows on every object or quality its fit proportion, neither more nor less,

$\mathrm{He}$ is the arbiter of the diverse, he is the key,

$\mathrm{He}$ is the equalizer of his age and land, ...

The years straying toward infidelity he withholds by his steady faith,

$\mathrm{He}$ is no arguer, he is judgment, (Nature accepts him absolutely,)

He judges not as the judge judges but as the sun falling round a helpless thing, ...

He sees eternity in men and women, he does not see men and women as dreams or dots. ${ }^{7}$

Whitman calls the poet-judge "the equable man"-setting his ideal in a tradition of thought about legal and judicial reasoning that stretches back to Aristotle, who developed a normative conception of equitable judgment as an alternative to a simple or reductive reliance on abstract principles. ${ }^{8}$ Whitman, like Aristotle, claims that this flexible context-specific judging is not a concession to the irrational, but the most complete expression of the

2 Walt Whitman, By Blue Ontario's Shore, lines 1-2, in Walt Whitman, Leaves of Grass 340, 340 (Norton, 1973) (Sculley Bradley and Harold W. Blodgett, eds).

3 Id line 3 at 340 .

4 Id line 128 at 346 ("I heard the voice arising demanding bards").

5 Id line 133 at 347.

6 Id lines $137-59$ at $347-48$.

7 Id lines $137-38,140-42,146-48,153$ at $347-48$.

${ }^{8}$ See Aristotle, Nicomachean Ethics 1137'27-32 (Oxford, 1894) (I. Bywater, ed). 
politically rational: not "in him" but "off from him" things "are grotesque, eccentric, fail of their full returns." The poet is no capricious whimsical creature, but the person best equipped to "bestow on every object or quality its fit proportion," duly weighing the claims of a diverse population, with his gaze fixed both on fairness ("he is the equalizer of his age and land") and on history ("the years straying toward infidelity he withholds by his steady faith"). Both fairness and history are to some extent at risk in a democracy because popular whim and prejudice may disregard them; Whitman alleges that the poet-judge is their protector though we have yet to see why this is so.

Whitman's Phantom then says some obscure and apparently contradictory things about the poet for whom he longs. First, "he is no arguer, he is judgment"; then, "he judges not as the judge judges but as the sun falling round a helpless thing." Why is the poet not an "arguer," but "judgment"? How can he be judgment, if he does not judge "as the judge judges"? And what mode of judging is suggested in the strange metaphor of light?

I suggest that the key to these puzzling lines is contained in the later line in which the poet "sees eternity in men and women, he does not see men and women as dreams or dots." Here the contrast is between an abstract pseudo-mathematical vision of human beings and a richly human and concrete vision that does justice to the complexity of human lives. This, I think, is also the way to read the contrast between being an "arguer" and being "judgment": the poet does not merely present abstract formal considerations, he presents equitable judgments, judgments that fit the historical and human complexities of the particular case. This, the Phantom now goes on to point out, is not the way of most current judges: thus the poet does not judge "as the judge judges." We can best get an idea of what his method is like, the Phantom suggests, by thinking of the way sunlight falls around a "helpless thing."

This complex image suggests enormous detail and particularity. When the sun falls around a thing, it illuminates every curve, every nook; nothing remains hidden, nothing unperceived. This intimacy is emphasized by the unusual location, "falls around," instead of "falls upon." So too the poet's judgment falls around all the complexities of a concrete case, perceiving all that is there and disclosing it to our view. ${ }^{9}$ In particular, the sun

9 The image is similar to Aristotle's image of the architect's flexible ruler that bends round to suit the complex shape of the stone. Id at $1137^{\mathrm{a}} 32-1138^{\mathrm{a}} 2$. 
illuminates the situation of the helpless, which is usually shrouded in darkness. But this intimacy is also stern and rather pitiless: by comparing judgment to sunlight rather than gentle shade, Whitman indicates that the poet's commitment to fairness does not yield to bias or favor; his confrontation with the particular, while intimate, is unswerving. There is an ideal of judicial neutrality here, but it is a neutrality linked not with quasi-scientific abstractness but with rich historical concreteness.

All of this is a description of judgment. It is also a description of the literary imagination. It is Whitman's startling claim that the literary imagination should play an important role in supplying these States with norms of legal and, especially, judicial reasoning, through an Aristotelian conception of practical judgment. 'I defend that claim, although I also insist that technical legal reasoning, knowledge of law, and the constraints of precedent play a central role in good judging and supply constraints within which the imagination must work. The judge cannot be simply a poet, or even simply an Aristotelian equitable man. Whitman neglects the institutional constraints on the judge's role, treating him as free to follow his own fancy; this is surely wrong. But I argue that, properly constrained, the imagining characteristic of a literary artist-and his attentive reader-can often supplement the other aspects of judicial reasoning in a valuable way, offering insight into a number of issues on which I shall later comment, including questions of sex equality, the range and significance of the right to privacy, and questions about what a reasonable person would do. I argue the literary/Aristotelian conception, combined with institutional constraints, yields a complex ideal of judicial neutrality that is a powerful rival to other influential conceptions of that norm. I explore that ideal of judicial neutrality in Section II, contrasting it to the judicial ideal proffered by Herbert Wechsler in his famous article, Toward Neutral Principles of Constitutional Law.

In Section III, turning to Whitman's claim that the poet is "the equalizer of his age and land," I develop the connection between the experience of the literary imaginer and a concern with social equality by focusing on the reader's response to two novels, Hard Times by Charles Dickens and Native Son by Richard Wright. Finally, in Section IV, I examine some judicial opinions that give both good and bad examples of the kind of judging Whitman recommends.

Three aspects of the literary imagination are of particular interest to me in pursuing this comparison: qualitative differenc- 
es, individual separateness, and appropriately constrained emotion. As readers of novels we enter worlds that are rich in qualitative distinctions. ${ }^{10}$ These distinctions seem highly salient; as readers we are actively discouraged from ignoring them or reducing them to quantitative distinctions. Indeed, identifying with a literary character requires sorting out qualitative sameness and difference, as the reader notices the ways in which a character whose human aims and aspirations are in some ways similar to her own also differs from her in situation and possibility.

At the same time, the reader begins to care about the character's life as a separate life. She notices that each human being has just one path through the world. Regarding each character with the respect and "wonder"11 that the form engenders, she thinks of each life as having significance in itself, not as a mere contributor to a social aggregation of satisfactions. ${ }^{12}$ She sees, for example, that the happiness of the prosperous does not ameliorate the distress of the poor.

As the reader wonders about the characters, finally, she is likely to feel emotions such as fear, compassion, and indignation, both toward them and on their behalf. These emotions have a special character. As Adam Smith argues, when he uses the experience of literary readership as a model for his notion of the "judicious spectator" or impartial judge, the literary form itself, by asking the reader to be a spectator to the fortunes of others rather than immersed in her own personal affairs, constrains and filters her emotions. ${ }^{13}$ The reader's emotions are genuine, and yet tempered by her noninvolvement: her fear, anger, and so forth will lack the special bias toward herself that is frequently found in real-life deliberations. For this reason, Smith held that the emotions of the judicious spectator were a valuable part of the spectator's equipment as a public reasoner. They provide ways of perceiving the good of others without bias or distortion. ${ }^{14}$

${ }^{10}$ This is discussed at length in Chapter Two of Nussbaum, Poetic Justice (cited in note $\dagger$ ).

11 See Charles Dickens, Hard Times 90 (Penguin, 1969). "Wonder" is Dickens's term for the combinstion of awe and curiosity with which the reader pursues the fates of the characters.

12 This topic and the contrast between the literary and the economic are the themes of Chapter Two of Nussbaum, Poetic Justice (cited in note $\dagger$ ).

13 Adam Smith, The Theory of Moral Sentiments 19-23 (Liberty, 1982). Further elaboration of this idea is the theme of Chapter Three of Nussbaum, Poetic Justice (cited in note $\dagger$ ).

14 See Smith, Theory of Moral Sentiments at 19-23. 
The thinking of a real-life judge may include the specifically literary aspects of my "literary judge." But the real-life judge must also have other abilities and knowledge, and is constrained in many ways by her institutional role and by the demands of statute and precedent, which already establish what she may and may not consider salient. The literary aspects of judging can readily be incorporated into an understanding of judicial reasoning that derives from the common-law tradition, with its Aristotelian emphasis on the concrete particular. But that tradition does not permit a judge to exercise untethered sympathy or "fancy."15 We must ask, then, how fancy operates within the confines of a formal judicial role.

\section{JUDICIAL NEUTRALITY}

The literary judge-like Whitman's beam of sunlight-is committed to neutrality, properly understood. That is, she does not tailor her principles to the demands of pressure groups, and she gives no group or individual special indulgence or favor on account of their relation to her interests. As a judicious spectator, she does not gush with irrelevant sentiment. On the other hand, she does not think of this sort of neutrality as requiring a lofty distance from the social realities of the cases before her. Indeed, she examines those realities searchingly, with imaginative concreteness and the emotional responses proper to the judicious spectator -or to her surrogate, the novel-reader.

A special concern for the disadvantaged is built into the structure of the literary experience, at least in many central cases of the realist novel, which from its inception proved controversial precisely on this account. ${ }^{16}$ The reader participates vicariously in numerous different lives, some advantaged and some disadvantaged. In the realist social novel, these lives are selfconsciously drawn from different social strata, and the extent to which these varied circumstances allow for flourishing becomes part of the reader's experience. She has empathetic emotions appropriate to the living of the life, and, more importantly, spectatorial emotions with which she evaluates the way fortune

${ }^{15}$ See Dickens, Hard Times at 52 (cited in note 11). Dickens uses the term "fancy" to describe the activity of seeing one thing in or as another. We might call this activity the metaphorical imagination.

${ }_{16}$ See generally Ian P. Watt, The Rise of the Novel: Studies in Defoe, Richardson and Fielding (Berkeley, 1967); Charles Taylor, Sources of the Self: The Making of the Modern Identity 286-89 (Harvard, 1989). 
has made this life conducive or not conducive to flourishing. This means, as I argue in Section III, that thinking of these possibilities as her own, she notices especially vividly, and with a special anxious concern, the disadvantages faced by the least well-off. Thinking that she might be any of these people, she will be especially concerned to ward off the bleakest possibilities. Reading Dickens's Hard Times, for example, she is likely to feel that given the disadvantages under which he labors, factory worker Stephen Blackpool requires a special degree of attention (more deliberative thought about his situation, and quite possibly social programs designed to alter it) if he is to be shown a truly equal concern as a citizen.

This description of the literary experience goes to the heart of the famous and controversial argument of Herbert Wechsler's Toward Neutral Principles of Constitutional Law. ${ }^{17}$ The literary judge/judicious spectator strongly agrees with the general view of judgment articulated near the beginning of the article: Judges need criteria that are not arbitrary or capricious, "criteria that can be framed and tested as an exercise of reason and not merely as an act of willfulness or will." "that rests on reasons with respect to all the issues in the case, reasons that in their generality and their neutrality transcend any immediate result that is involved." The reasons should meet a standard of public articulability and principled consistency. We should strongly resist the idea that the courts do or should operate as "naked power organ[s]."

A similar idea of neutrality and freedom from situational bias also motivates Smith's judicious spectator who is himself constructed by analogy to the reader of narrative fiction. Where legal reasoning is concerned, we need to add to Smith's model the fact that there will also be institutional constraints on the judge's reasoning; this gives us yet a further reason to agree with Wechsler in his demand for principled neutrality.

As his argument continues, however, Wechsler turns sharply away from Smith's ideal of neutrality to a more remote and abstract norm. He seems to take the demand for neutrality to entail standing at such a distance from present circumstances and their history that one ignores many specific social and historical facts

\footnotetext{
1773 Harv L Rev 1 (1959).

18 Id at 11.

19 Id at 19.

20 Id at 12.
} 
that seem, in fact, highly relevant to the equal and principled application of the law. Although in the theoretical part of the article Wechsler insists that his conception of principle does not entail disregarding history and legal precedent, in his reading of the school desegregation cases he appears to disregard some highly pertinent social data, in the name of sticking to "the facts."21 In particular, when discussing "separate but equal" facilities, he suggests that judges should refuse themselves concrete empathetic knowledge both of the special disadvantages faced by minorities and of the asymmetrical meaning of segregation for blacks and whites:

[T]he separate-but-equal formula was not overruled "in form" but was held to have "no place" in public education on the ground that segregated schools are "inherently unequal," with deleterious effects upon the colored children in implying their inferiority, effects which retard their educational and mental development.

I find it hard to think the judgment really turned upon the facts. Rather, it seems to me, it must have rested on the view that racial segregation is, in principle, a denial of equality to the minority against whom it is directed. . . . But this position also presents problems.... In the context of a charge that segregation with equal facilities is a denial of equality, is there not a point in Plessy in the statement that if "enforced separation stamps the colored race with a badge of inferiority" it is solely because its members choose "to put that construction upon it"? Does enforced separation of the sexes discriminate against females merely because it may be the females who resent it and it is imposed by judgments predominantly male? Is a prohibition of miscegenation a discrimination against the colored member of the couple who would like to marry?

For me, assuming equal facilities, the question posed by state-enforced segregation is not one of discrimination at all. Its human and its constitutional dimensions lie entirely elsewhere, in the denial by the state of freedom to associate, a denial that impinges in the same way on any groups or races that may be involved. I think, and I hope not without foundation, that the Southern white also pays heavily for 
segregation, not only in the sense of guilt that he must carry but also in the benefits he is denied. In the days when I was joined with Charles $\mathrm{H}$. Houston in a litigation in the Supreme Court, before the present building was constructed, he did not suffer more than I in knowing that we had to go to Union Station to lunch together during the recess. ${ }^{22}$

Wechsler claims to state not only the constitutional but also the "human" meaning of the laws in question. He is wrong on both counts. There is such a lofty distance from the human facts of the matter that the principles are incorrect. Had Wechsler imagined the lunch incident in the manner of a novelist, considering the meaning, for Houston, of knowing that he could not lunch with Wechsler at a downtown restaurant, he would quickly have seen that the meaning of that denial of the freedom to associate is strongly asymmetrical-for Wechsler, an inconvenience and a source of guilt; for Houston, a public brand of inferiority. One cannot consider the history of race relations in this country closely and sympathetically, in the manner of Smith's judicious spectator, without noticing this asymmetry. Wechsler's claim that the issue is not one of discrimination at all has a bizarre sort of Martian neutrality. From his enforced distance from the emotions involved in the experience of oppression, he fails to notice perfectly reasonable and universalizable principles that do include the asymmetrical meaning of segregation and the history of segregation as stigma. These notions of stigma and brand are highly relevant to the interpretation of the Constitution and to the formulation of appropriate constitutional, as well as human, principles. One cannot, for example, even begin to address Wechsler's claim that freedom of association is a better constitutional principle to invoke than equal protection before one sees what the equal protection issue is all about. This, I argue, Wechsler's approach prevents him from doing.

Wechsler's failure of imagination is equally evident in the gender example, which, it would seem, is intended to serve as a reductio ad absurdum of his racial point: if separate-but-equal is wrong for race, it must be wrong for gender. "Does enforced separation of the sexes discriminate against females merely because it may be the females who resent it and it is imposed by judgments predominantly male?"23 This trivializes the argument a

\footnotetext{
$\approx$ Id at 33-34, quoting Learned Hand, The Bill of Rights 54 (Harvard, 1958).

23. Wechsler, 73 Harv $L$ Rev at 33 (cited in note 17).
} 
feminist would make, for enforced separation of the sexes is frequently a source not only of discomfort and "resentment" for women, but also of substantial social disadvantages that can be articulated in a principled way. There are many ways in which the historical asymmetry between men and women can be made the subject of principled argument, argument that rests on reasons and is not simply tailored to achieve a particular concrete result.

The literary judge/judicious spectator, by contrast, holds that such social and historical facts are relevant, and that the judge in such a case should develop as rich and comprehensive an understanding as possible of the situation of the groups involved in the case. She should not be swayed by any personal connection or any partisan goal. Her emotions should be those of the judicious spectator, not personal emotions bearing on her own interests. They should not simply be the emotions of the actors involved, although empathy with the actors is usually one important part of the process of judicious spectatorship through which the judge takes the measure of their suffering into account.

The judicious spectator must also assess the significance of the suffering from her own spectatorial viewpoint. People can go wrong about what is happening to them in many ways. As spectators, we may find that Stephen Blackpool exaggerates the wrong done to him by society; or we may find, as I think we really do when we read Dickens, that his political deprivations have made him-if anything - too well-adapted to his misery, too ready to accept a small relief rather than demanding full equality. So detached evaluation is at the heart of the activity of the literary imaginer as judicious spectator.

Detached evaluation, however, does not mean being ignorant or refusing to acknowledge sufferings and inequities that are all too much a part of history. Literary neutrality, like Whitman's sunlight, like the reading of a novel, gets close to the people and their actual experience. That is how it is able to be fair.

\section{THE EquALIZER OF His AGE AND LAND}

Whitman calls his poet-judge an "equalizer." Let us now pursue that issue further. Why should the literary imagination be any more connected with equality than with inequality, or with democratic rather than aristocratic ideals?

When we read a realist social novel such as Dickens's Hard. Times, our attention has a special focus. Since the sufferings and anxieties of the characters are among the central bonds between 
reader and work, we notice in particular those characters who suffer and fear. Characters who are not facing any adversity simply do not hook us in; there is no drama in a life in which things are going smoothly. ${ }^{24}$ This tragic sensibility leads the reader to investigate, with identification and sympathy, lives in which circumstance has played an impeding role. Sometimes, of course, the baneful circumstances are inevitable. Loved ones die, natural disasters destroy property and cities. Frequently, however, the tragedy that moves us is not necessary. Not all wars are inevitable; hunger and poverty and miserably unequal conditions of labor are not inevitable. Since we read a realist social novel with the thought that we ourselves might someday be in such a position-since our emotion is based in part on empathetic identification-we are naturally most concerned with the lot of those whose position is worst, and we begin to think of ways in which that position might have been other than it is, might be made (for us, should we be in a similar position) better than it is.

One way in which the situation of the poor or politically oppressed is especially bad is that, at least in many cases, it might have been otherwise. This unrealized possibility is particularly clear when we see their situation side by side with that of the rich and prosperous. In this way, given that identification with the possibilities of the sufferer are built into our emotions of pity and fear, our thought will naturally turn toward making their lot more similar to that of the rich and powerful. Since we ourselves might be or become either, we want to raise the floor. ${ }^{25}$ This may not get all the way to complete equality, whether of resources or welfare or capabilities, but it does at least lead political thought toward ameliorating persistent inequalities and providing all with a decent minimum.

One might of course have these thoughts without being a "poet." But it is Whitman's point, I think, that the ability to imagine vividly and then to assess judicially another person's pain, to participate in it and then to ask about its significance, is a powerful way to learn what the human facts are and to acquire

${ }^{24}$ For further discussion of this issue, see Martha C. Nussbaum, Tragedy and Selfsufficiency: Plato and Aristotle on Fear and Pity, in Amélie Oksenberg Rorty, ed, Essays on Aristotle's Poetics 261 (Princeton, 1992); Martha C. Nussbaum, Poetry and the passions: two Stoic views, in Jacques Brunschwig and Martha C. Nussbaum, eds, Passions \& Perceptions: Studies in Hellenistic Philosophy of Mind, Proceedings of the Fifth Symposium Hellenisticum 97 (Cambridge, 1993).

${ }^{25}$ See John Rawls, A Theory of Justice 136-42 (Harvard, 1971) (discussing decisionmaking behind the "veil of ignorance"). 
a motivation to alter them. If one could not imagine what it was like to be Stephen Blackpool, then it would be all too easy to neglect his situation as does Josiah Bounderby, portraying workers as grasping, insensitive beings. ${ }^{26}$ Similarly, to take a case that will figure in my next Section, if one cannot imagine how women suffer from sexual harassment on the job, one cannot have a vivid sense of such harassment as a serious social offense that the law should remedy. ${ }^{27}$ In neither case does the judicious spectator stop with the experience of the other person's pain. She must then ask, from the spectatorial viewpoint, whether that pain is appropriate to its target, whether it is such pain, or anger, or fear, as a reasonable person would feel in those circumstances. But the sense of what was really experienced is a crucial step, without which any spectatorial assessment will likely be off the mark.

The literary judge is an equalizer in another closely related way. I argue that the experience of novel-reading, immersing the reader in the particular, yields a strong commitment to regard each life as both qualitatively individual and separate from other lives. This way of seeing things is relevant to the questions of well-being I have just addressed: Stephen's misery is not bought off by Bounderby's good fortune. But recognizing individuals as such has another kind of significance as well. Group hatred and oppression is very often based on a failure to individualize. Racism, sexism, and many other forms of pernicious prejudice frequently ground themselves in the attribution of negative characteristics to the entire group. Sometimes-as in the case of Nazi depictions of Jews, as in the case of much of the "thinking" characteristic of American racism-this is carried to the extreme of portraying the group as altogether subhuman, as vermin, insects, even as cargo. This attitude does not survive the individualized knowledge of a member or members of that group. This does not mean that even in contact with an individual one cannot find many ways of dehumanizing him or her in thought. It means, however, that when one does manage to apply the literary atti-

${ }^{26}$ The novel Hard Times concerns Mr. Gradgrind's attempt to educate his two children, Louisa and Tom, as perfect utilitarians, in a model utilitarian school in the factory town of Coketown. Louisa grows up emotionally stunted, and marries rich industrialist Josiah Bounderby at her father's request. Meanwhile, circus girl Sissy Jupe, resisting her new education at Gradgrind's hands, shows him its limits. A subplot concerns factory worker Stephen Blackpool. The miserable conditions of Blackpool's life are central to the novel's social criticism.

${ }^{27}$ See Section IV.B. 
tude of sympathetic imagining to the individual, the dehumanizing portrayal is unsustainable-at least for a time. A memorable moment of this kind is the scene in the film Schindler's List, in which the German camp commandant holds his Jewish housemaid by the chin, as she stands terrified in her slip, and asks, torn between dogma and personal desire, "Is this the face of a rat?"

Literary understanding, I would therefore argue, promotes habits of mind that lead toward equality in that they contribute to the dismantling of the stereotypes that support group hatred. Thus, in principle many literary works would be valuable: in reading Dickens, we learn habits of "fancying" that we can then apply to other groups that come before us. But it is also valuable to gain this literary understanding in a more concrete way, seeking out literary experiences in which we do identify sympathetically with individual members of oppressed groups within our own society, learning both to see the world, for a time, through the eyes of a member of such a group and then to reflect on the meaning of what we have seen.

Richard Wright's novel, Native Son, provides one example of this literary experience. ${ }^{28}$ As I taught this novel to an almost entirely white group of law students in the very place where the novel is set, many recognized that most of us were, in effect, in the position of the novel's Mary Dalton: well-meaning but ignorant and undeveloped in sympathy, desirous of knowing what it is like to live on the other side of "the line," but unable or unwilling to carry that desire into action. The experience of reading and discussing the novel at least begins to give the white reader a knowledge of her ignorance and to introduce habits of "fancying" that are crucial to develop if we are to deliberate well about race.

Wright's novel is "equalizing" in both of the ways that I have mentioned-both drawing our attention to misery and focusing our attention on the individual. From the first, we see the world through the eyes of a particular person who encounters special and terrible disadvantages. We enter a squalid one-room tenement where Bigger Thomas lives with his mother, his sister, and

2s Richard Wright, Native Son (HarperPerennial, 1993). Wright's novel tells the story of Bigger Thomas, a young black man from Chicago's South Side who is offered a job as chauffeur to the wealthy, white, liberal Dalton family. He kills the Daltons' daughter, Mary, in a manner that is ambiguous between accident and homicide, and then, while on the run, brutally murders his own lover Bessie. He is arrested, tried, convicted, and executed-for the Dalton killing only, the murder of Bessie being more or less totally ignored. 
his brother. "Light flooded the room and revealed a black boy standing in a narrow space between two iron beds . . . ." ${ }^{\prime 29}$ Bigger, seen by the sun-an image that strikingly recalls Whitman's sun "falling round a helpless thing"-is in prison already. Like the rat he shortly kills, he is cornered, trapped, in a condition of helplessness. We see what it is to try to maintain self-respect and order when you have no privacy to change your clothes, when your pathetic "conspiracy against shame" any time by a rat running across the floor. We note the way in which the rat, cornered, strikes back viciously-and we sense what Bigger's relation to the world will be. In short, as we follow events both through Bigger's eyes and as onlookers, we see how at every point his hopes and fears, his sexual longings, and his sense of himself are all conditioned by the squalor of his surroundings.

Not only squalor. The dominant force in Bigger's self-conception and in his emotional life is racial inequality and hatred. He is aware of himself in images drawn from the white world's denigration of him; he defines himself as worthless because the white world has so defined him. Like the rat, he strikes back, attempting to use violence as an escape from helplessness and shame. The novel avoids evoking an easy kind of sympathy that would say that, despite differences in circumstance, we are all brothers under the skin. The white reader has difficulty identifying with Bigger because his emotions and desire are strange to such a reader, shaped, as they are, by his circumstances. But beneath the facile kind of sympathy lies the possibility of a deeper sympathy, one that says: this is a human being, with the basic equipment to lead a productive human life; and see how not only external circumstances, but also anger, fear, and desire have been deformed by racial hatred and its institutional expression. The unlikeness that repels identification becomes the chief object of our concern.

The reader's experience here shows very clearly what role empathy does and does not play in the activity of the judicious spectator. We cannot follow the novel without trying to see the world through Bigger's eyes. As we do so, we take on, at least to some extent, his emotions of rage and shame. On the other hand, we are also spectators; as spectators we recognize the inappropriateness of some of his emotions to their object-the inappropri-

29 Id at 1.

so Id at 2. 
ateness, for example, of his shame at the color of his skin, and of his tragic combination of longing and fear toward the white family. These emotions are all too plausible given his situation; yet the novel shows their cruel and arbitrary social basis. This leads us as spectators to feel a further range of emotions-a deep sympathy, as I have suggested, for Bigger's predicament, a principled anger at the structures of racism that have made him as he is.

"He knew as he stood there that he could never tell why he had killed. It was not that he did not really want to tell, but the telling of it would have involved an explanation of his entire life."31 As a "judicious spectator" of Bigger's story, the reader-unlike almost all of the characters-attends to the explanation of Bigger's entire life and comes to an understanding of the genesis of his violent character. The novel suggests that this understanding is essential to the just assessment of Bigger's crime. Many other issues must be taken into account by a judge or juror, many of them technical in character. Even the constraints built into the ideal of judicious spectatorship need to be further constrained by specifically legal requirements. But while judging Bigger culpable (the degree of his culpability is certainly debatable), the reader is likely to be, other things equal, inclined to mercy in the imposition of punishment, seeing how much of his character was the product of circumstances created by others. $^{32}$

What the narrative shows us, however, is that in the world in which Bigger Thomas actually lives, with its institutional and legal barriers to mobility, with its racial estrangement and mutual fear and hate, the characters, unlike the novel reader, cannot empathize with others as full individuals across racial lines. Neither Bigger nor the white characters can see members of the other race as separate distinct individuals, each with their own story to tell. The racial branding of individuals eclipses personal identity. To Bigger, white people are a "looming mountain of white hate ...."33 $\mathrm{He}$ cannot see them as individuals, and indeed the prospect of an individual relationship with Mary Dalton arouses such fear and shame and loathing in him that he is led

${ }^{31}$ Id at 356.

32 See Martha C. Nussbaum, Equity and Mercy, 22 Phil \& Pub Affairs 83 (Spring 1993). See also the fuller discussion of the judicious spectator as norm for the juror in Chapter Three of Nussbaum, Poetic Justice (cited in note $\dagger$ ) (including a discussion of the role of narrative in several capital sentencing cases).

${ }^{33}$ Wright, Native Son at 333 (cited in note 28). 
to the brink of rape and, subsequently, to manslaughter. ${ }^{34}$ Mary Dalton attempts to befriend Bigger as an individual, but in a clumsy, ill-judged way. Her perception of him as individual is usually obscured by stereotypes; he is little more to her than a means to rebel against her parents. ${ }^{35}$ The novel makes us doubt that any other more personal relationship would have been possible, except in the most unusual circumstances. The legacy of racism has made literary judging-and with it, friendship and constructive partnership-impossible. In this sense, the novel is about itself and recommends its own attitudes as politically superior to those encouraged by racial hierarchy. Its most powerful charge against America is that its own modes of perception are virtually unavailable.

The novel is well known for the speech of Bigger's lawyer, who, borrowing from Frantz Fanon, sees violence as an inevitable response to oppression, perhaps even a valuable sort of self-assertion. ${ }^{36}$ But it is not on this note that the novel ends; the lawyer is shown to be just as deaf to Bigger's personal story as many of the other white characters. The novel ends, in fact, with the achievement of sympathy and friendship. During his long imprisonment, Bigger is struck by the courage and decency of Jan, the young communist who has every motive to hate him, but who alone seems to attend to him as a person in his own right. Bigger begins to think like a novel-reader. He begins, that is, to think of the deep similarity in human aims and insecurities that may exist on both sides of the racial barrier, although concealed from view by the social deformation of desire. In a sudden epiphany, he becomes able to see this common humanity:

He wondered if it were possible that after all everybody in the world felt alike? Did those who hated him have in them the same thing Max had seen in him, the thing that had made Max ask him those questions? And what motive could Max have in helping? Why would Max risk that white tide of hate to help him? For the first time in his life he had gained a pinnacle of feeling upon which he could stand and see vague relations that he had never dreamed of. If that white looming mountain of hate were not a mountain at all, but people, people like himself, and like Jan-then he was faced

\footnotetext{
34 Id at 95-100.

35 Id at 50-90.

36 Id at 444-73.
} 
with a high hope the like of which he had never thought could be, and a despair the full depths of which he knew he could not stand to feel. . . . He stood up in the middle of the cell floor and tried to see himself in relation to other men, a thing he had always feared to try to do, so deeply stained was his own mind with the hate of others for him. ${ }^{37}$

Racial hatred is a stain and an infection that prevents the individualized, and at the same time the common, view of the humanity of others. These two perceptions are connected because seeing others as similarly and fully human entails seeing them as individuals with their own stories to tell. To see white people not as a looming mountain of hate but as people-this is the beginning of hope. But in Bigger's circumstances, as he faces death, it is also despair-for there was, then, a real human life and a human community. He discovers its worth at the same time that he realizes his own irrevocable loss of it. The despair encompasses, as well, the knowledge that the forces that have doomed him persist unchanged, that it will take large-scale changes that he cannot even imagine to make that hope a reality for others. His last words in the novel are, "Tell Jan hello"-and then, "Goodbye!" Then "[h]e heard the ring of steel against steel as a far door clanged shut.".38

By engaging the reader in this tragedy of social helplessness, the novel constructs a neutral judge of Bigger Thomas, but a judge whose neutrality is different in kind from Wechsler's and far closer to Whitman's. The stigma and brand of racial hate and shame are seen to deform human personality and community; the novel-reading stance calls out for political and social equality, as the necessary condition of full humanity for citizens on both sides of "the line."

Native Son's connection between literary "spectatorship" and a concern for equality is not an isolated phenomenon. Another example ${ }^{39}$ (among the many that could be mentioned) is E.M. Forster's Maurice, ${ }^{40}$ which deals with one of the most pressing equality issues of our time. Maurice was written in 1913-14, but published only in 1971. It could not have been published earlier, its author tells us, because it shows a homosexual love ending

\footnotetext{
37 Id at 418.

${ }^{39}$ Id at 502 .

39 The reading of Dickens's Hard Times, in Chapters Two and Three of Nussbaum, Poetic Justice (cited in note $\dagger$ ), is another contribution to this project.

10. E.M. Forster, Maurice: A Novel (Norton, 1993).
} 
happily. "Happiness is its keynote .... If it ended unhappily, with a lad dangling from a noose or with a suicide pact, all would be well, for there is no pornography or seduction of minors. But the lovers get away unpunished and consequently recommend crime.".41

The strategy in Maurice is to portray a man of strong and exclusive homosexual tendencies who is in no other way unusual or atypical. In fact, he is a boring, snobbish, middle-class English stockbroker of mediocre talent and imagination. The reader is not thrilled by him, but his kindness and his general good nature evoke sympathy. The emotional structure of the novel relies on the ease with which the reader sees Maurice as average. The reader then sees, year by year, how the treatment society accords to Maurice's desires, which revolve around rather tender imaginings of a comforting and quasi-marital "friend," renders him terribly nonaverage and also unequal. From the anatomy lecture on the beach, where the young teacher's quasi-Biblical praise of the naturalness of heterosexuality makes the boy feel his own "nature" and impulses to be shameful and deformed, ${ }^{42}$ to the Terminal Note, in which Forster reminds us that even in 1960, when the note was written, homosexuals continued to be prosecuted for consensual sexual acts, ${ }^{43}$ the novel tells a story of average humanness forced into a situation of repression, fear, and guilt. This inequality is enforced by social prejudices that justify themselves with a language of nature that derives from religious tradition. The reader is led to recognize that Maurice is someone she might know and someone whose desires are not alarming or dangerous. He wants many of the same things heterosexuals want. The reader also recognizes that the desires that lead Maurice to other men are in their own way deeply "natural"-in him from an early age in a way he neither chooses nor controls. The psychiatrist who fails to "cure" him, for example, recommends a move to France, saying "England has always been disinclined to accept human nature." ${ }^{\prime 44}$ For the person who finds himself to be heterosexual, society gives respect and status; but the person who finds himself to be different receives only frustration, shame, and continual danger. When Maurice's friend Clive marries, "[b]eautiful conventions receive[ ] them-while beyond the

\footnotetext{
4 E.M. Forster, Terminal Note, in Forster, Maurice at 250 (cited in note 40).

42 Forster, Maurice at 13-15 (cited in note 40).

43 Forster, Terminal Note in Forster, Maurice at 255 (cited in note 40).

44 Forster, Maurice at 211 (cited in note 40 ).
} 
barrier Maurice wander[s], the wrong words on his lips and the wrong desires in his heart, and his arms full of air." ${ }^{245}$

Although in many ways this novel is extremely distant from Native Son-it is set in a sheltered middle-class world, its characters are refined and nonviolent-its common ground is evident. The image of "the barrier" reminds us of "the line" that separates black from white in Bigger's world. In both cases there is a division in society that marks some people as normal and good, others as shameful and evil. In both cases this division brands and stigmatizes the excluded group in ways that are closely connected to systematic inequalities: Maurice may be able to hold a job, but he cannot express his sexual desires openly, he lives continually at risk of prosecution, and he cannot have honest relationships with his friends and fellow workers. In a very real sense, he is not a fully equal citizen. Clive, having chosen to forgo homosexual gratification and to enter a passionless marriage, is also unequal-for he is forced to lead an essentially dishonest life in a matter of the greatest importance. The novel's last sentence tells us that Clive, having heard of Maurice's affair with Alec, "returned to the house, to correct his proofs and to devise some method of concealing the truth from Anne [his wife]." ${ }^{\text {"46 }}$ Forster notes that Clive and Maurice come as close to equality with heterosexuals as they do only because they enjoy class advantages that Maurice's lower-class lover, Alec, lacks. Even in the Britain of 1960, unless consensual homosexual acts are decriminalized, "Clive on the bench will continue to sentence Alec in the dock. Maurice may get off." ${ }^{m 7}$ In that way, issues of class equality are linked to the novel's central issue of sexual equality.

The novel, like Native Son and Hard Times, refers to itself. Again and again the reader notices that she sees Maurice differently than do the people around him. Maurice's friends either refuse recognition of his difference or, recognizing it, shun him in horror as if he had suddenly become a monster. They simply cannot permit themselves to imagine for a moment what it might be like to be him. The reader, who does imagine, is fully aware all along that Maurice is neither the same as those around him nor a monster. This means that the reader is aware, in a way the characters are not, of the stigmatizing effect of prejudice, and of the helplessness it creates. The novel makes its case for equal

\footnotetext{
45 Id at 165.

46 Id at 246.

47 Forster, Terminal Note in Forster, Maurice at 255 (cited in note 40).
} 
sexual liberty by showing the profound worth of that liberty in its portraits of the flourishing of Maurice and the stunted life of Clive; it enlists the reader as a partisan of that equality by making it easy for the reader to see Maurice as one whom the reader, or a friend or loved one, might be.

\section{Poetic JUdGING}

My argument is well captured in the quotation from Stephen Breyer's confirmation hearing that I cited as an epigraph. The ability to think of people's lives in the novelist's way is, Breyer suggests, an important part of the equipment of a judge ${ }^{48}$-not the whole, or even the central part, but a vital part nonetheless. This claim is the more impressive in that it comes from a judge who is far from being a sentimentalist, whose technical proficiency is great, and who is, if anything, considered more intellectual than emotional. My approach-like, I believe, the approach that Breyer sketched in his statement-stresses the need for technical mastery as well as sentiment and imagination, and insists that the latter must continually be informed by and tethered to the former.

In order to go further, however, we need examples of judicial opinions that do and do not manifest the virtues of the literary judge. I have selected two positive examples and one negative.

\section{A. Hudson v Palmer ${ }^{49}$}

The case was brought by Palmer, a prison inmate serving a sentence for forgery, grand larceny, and bank robbery, against Hudson, a police officer who had conducted a shakedown search of his cell..$^{50}$ Palmer claimed that the search was conducted solely to harass or humiliate him ${ }^{51}$ and that Hudson, under the pretense of searching for contraband, intentionally destroyed some of his legitimate personal property, including photographs and letters. ${ }^{52}$ Palmer claimed that this destruction of property violated his Fourth Amendment right to be free from unreasonable

48 See text accompanying note 1 .

49468 US 517 (1984).

so Id at 519-20.

51 Id at 520. Hudson and an accompanying officer found a ripped pillowcase in the waste basket, and as a result brought charges against Palmer for destroying state property. He was ordered to reimburse the state, and a reprimand was entered on his record. Id at 519-20.

${ }^{52}$ Id at 541 (Stevens concurring in part and dissenting in part). 
searches and seizures and that the unauthorized deprivation of property constituted a violation of the procedural due process requirement of the Fourteenth Amendment. ${ }^{53}$

In an opinion written by Chief Justice Burger, the majority held that a prison inmate did not have "a reasonable expectation of privacy in his prison cell entitling him to the protection of the Fourth Amendment against unreasonable searches and seizures, ${ }^{254}$ and that therefore even the modest requirement that random searches should be conducted within certain established guidelines, as the Court of Appeals had required, constrained prison power too severely. ${ }^{55}$ "The recognition of privacy rights for prisoners in their individual cells simply cannot be reconciled with the concept of incarceration and the needs and objectives of penal institutions. ${ }^{156}$ As for the intentional destruction of property, that did not violate due process as long as the state provided "a meaningful postdeprivation remedy."57

Justice Stevens, joined by Justices Brennan, Marshall, and Blackmun, concurred in part and dissented in part. He agreed with respect to the due process issue, but claimed that the Court's reasoning on the Fourth Amendment issue was "seriously flawed," indeed "internally inconsistent.. ${ }^{.58}$ It was inconsistent because the Court granted the possibility of maliciously motivated searches and intentional harassment of prisoners, saying that these "cannot be tolerated by a civilized society. ${ }^{159}$ But,

the Court then [held] that no matter how malicious, destructive, or arbitrary a cell search and seizure may be, it cannot constitute an unreasonable invasion of any privacy or possessory interest that society is prepared to recognize as reasonable.

Measured by the conditions that prevail in a free society, neither the possessions nor the slight residuum of privacy that a prison inmate can retain in his cell, can have more than the most minimal value. From the standpoint of the

63 Palmer, 468 US at 520.

s4 Id at 519.

*5 Id at 529 .

56 Id at 526.

57 Id at 531.

ss Id at 541-42 (Stevens concurring in part and dissenting in part).

59 Id at 542, quoting the majority opinion at 528 . 
prisoner, however, that trivial residuum may mark the difference between slavery and humanity.

Personal letters, snapshots of family members, a souvenir, a deck of cards, a hobby kit, perhaps a diary or a training manual for an apprentice in a new trade, or even a Bible-a variety of inexpensive items may enable a prisoner to maintain contact with some part of his past and an eye to the possibility of a better future. Are all of these items subject to unrestrained perusal, confiscation, or mutilation at the hands of a possibly hostile guard? ${ }^{60}$

Stevens then continued with a legal argument. He first distinguished between Palmer's privacy and possessory interests. ${ }^{61}$ Although he rejected the Court's general rule that a prisoner can have no expectation of privacy in his papers or effects, here he accepted that rule for the purposes of his argument. He then argued that the Fourth Amendment at least protects Palmer's possessory interest in the property. He pointed out that Palmer's possession of the destroyed material was legitimate as a matter of state law; therefore the Court was wrong to conclude that, as a prisoner, he could have no legitimate possessory interests. ${ }^{62} \mathrm{He}$ also pointed out that in its treatment of Palmer's due process claim the Court itself granted that the destroyed material was "property" within the meaning of the due process clause. ${ }^{63}$

Hudson's actions, then, constituted a "seizure." ${ }^{\text {"4 }}$ Was the seizure "unreasonable"? This question could only be answered by "balancing the intrusion on constitutionally protected interests against the law enforcement interests justifying the challenged conduct." ${ }^{\text {"65 }}$ Stevens argued that there was no legitimate penological justification for the seizure of Palmer's property. There was no contention that the property was contraband or posed any risk to institutional security. Hudson had already examined it before he destroyed it. No motive but spite was suggested for his conduct. Since the Court itself acknowledged that

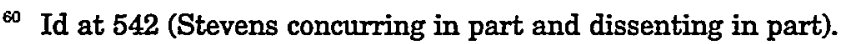

62 Id at 543 .

62 Id at 545 .

63 Id at 545-46. Stevens added arguments deriving from the First and the Eighth Amendments that I shall not consider here.

64 Id at 543-44, citing United States v Jacobsen, 466 US 109, 113 (1984) ("A 'seizure' of property occurs when there is some meaningful interference with an individual's possessory interests in that property.").

${ }^{65}$ Palmer, 468 US at 547 (Stevens concurring in part and dissenting in part). 
the intentional harassment of prisoners cannot be tolerated by a civilized society, this would seem to make the seizure unreasonable even by the Court's own lights.

Stevens next argued that legitimate institutional goals could not plausibly be said to outweigh Palmer's interests:

Depriving inmates of any residuum of privacy or possessory rights is in fact plainly contrary to institutional goals. Sociologists recognize that prisoners deprived of any sense of individuality devalue themselves and others and therefore are more prone to violence toward themselves or others. ${ }^{66}$

The argument that institutional needs outweigh Palmer's rights needed no sociological evidence to rebut it, Stevens went on to argue, for it was sufficiently rebutted by the fact that prison rules themselves permitted Palmer to possess this property. There could be no institutional need for seizure and destruction of items that were defined by the rules themselves as noncontraband.

To accord prisoners any less protection is to declare that the prisoners are entitled to no measure of human dignity or individuality-not a photo, a letter, nor anything except standard-issue prison clothing would be free from arbitrary seizure and destruction. Yet that is the view the Court takes today. It declares prisoners to be little more than chattels, a view I thought society had outgrown long ago. ${ }^{67}$

Stevens ended his opinion with a more general set of reflections. After noting that prisoners were not wholly stripped of constitutional protections, he insisted that traditionally the courts had a special duty to protect the rights of the powerless and the outcast against claims of mere expediency:

The courts, of course, have a special obligation to protect the rights of prisoners. Prisoners are truly the outcasts of society. Disenfranchised, scorned and feared, often deservedly so, shut away from public view, prisoners are surely a "discrete and insular minority." In this case, the destruction of Palmer's property was a seizure; the Judiciary has a constitutional duty to determine whether it was justified. ...

\footnotetext{
66 Id at 552.

67 Id at 554-55.
} 
By telling prisoners that no aspect of their individuality, from a photo of a child to a letter from a wife, is entitled to constitutional protection, the Court breaks with the ethical tradition that I had thought was enshrined forever in our jurisprudence. ${ }^{68}$

In assessing this opinion, I shall focus not on the merits of the constitutional argument, but on what might be called the literary aspects of Stevens's consideration of Palmer. Stevens's opinion is not especially emotional in any obvious sense. Nor is it rhetorically self-conscious; it is not "literary" in the sense of being stylistically impressive. It does, however, seem to me to embody some of the central traits of the literary "judicious spectator" whom I have imagined. Consider the view of Palmer presented by the opinion. Like Wright's reader face-to-face with the individuality of Bigger Thomas, Stevens (and therefore his reader) confronts the separateness and individuality of Palmer the prisoner, imagining the significance of trivial items such as letters and photos for his humanity and his hope of a better life. Rather than treating the prisoner simply as a body to be managed by institutional rules, he treats him as a citizen with rights and with a dignity that calls forth respect. $\mathrm{He}$ is able to enter into the existence of one who is (rightly) feared and loathed by society. In the manner of a judicious spectator, Stevens sees the interests and rights of the prisoner, as well as his special circumstances, without fully sharing his emotions and motives. Whereas the majority opinion made no attempt to imagine the prisoner's legitimate interest in his property, Stevens does imagine this interest in a way that both takes cognizance of the difference between the prisoner and other citizens and, at the same time, recognizes the common human concerns that connect them-concerns for family, for reminders of home, for self-improvement. Stevens positions himself as a neutral and impartial spectator; he is careful to indicate that his reasoning is not tailored to an immediate political result. Indeed, he generalizes about the class of prisoners throughout, emphasizing the representative character of the case and thus the universalizable character of his judgment. In that way his opinion is closely linked, in literary terms, to the generalizing strategies of the ancient tragic chorus: one might compare Sophocles' depiction of the outcast Philoctetes, with his small sunless cave, his rudimentary cup, the disfiguring wound that

6 Id at 557-58. 
revolted all normal citizens. ${ }^{69}$ In both cases, a few details make vivid to us the general structure of a life of disadvantage.

How are these "literary" aspects of the opinion relevant to the case? The majority claimed that institutional expediency took precedence over the prisoner's claims. In so arguing, they obscured from view the humanity of the prisoner, the interests and rights that link him to other constitutionally protected members of society. Stevens's depiction of those common interests gives vivid support to his contention that Palmer has legitimate possessory interests, that these have been invaded, and that the search was in that sense "unreasonable." He might have made the same argument without these details; but they remind us forcefully of the general point that prisoners are citizens and do have rights, that they may not be treated as mere objects. It is noteworthy that the majority opinion concurred in these general sentiments, insisting that a civilized society may not tolerate merely malicious searches. Yet Stevens's imagining of the case gives those ideas a life that they perhaps lacked in the reflections of the majority, and thus makes clear the depth of the problem of consistency in their opinion.

At the same time, the literary aspects of the opinion bear on the question of Hudson's malice. If we can imagine the items seized in the shakedown search-a photograph, a letter-we can imagine not only the fact that Palmer possessed these items legitimately but also the character of the interest he was likely to have in these fragile signs of his humanity. We are likely, then, to appreciate more vividly the malicious character of the intrusion of the guard, whose destruction of a photograph served no conceivable institutional goal other than intimidation and humiliation. The majority said that intentional harassment and maliciously motivated searches could not "be tolerated in a civilized society." By imagining Palmer's situation in detail, Stevens was able to make a strong argument that this case was exactly what could not be tolerated. In summary, Stevens could have made his argument without the elements I have called "literary." But these elements contribute to his argument that the search was unreasonable and that it constituted malicious intentional harassment of the sort that the majority had judged intolerable.

Stevens's concluding reflection grows out of and is buttressed by the way he imagines the prisoner's dignity and humanity. $\mathrm{He}$

${ }^{69}$ Sophocles, Philoctetes lines 15-39 at 295-96 (Oxford, 1990) (H. Lloyd Jones and N.G. Wilson, eds). 
reflects that, in general, the Constitution stands between human beings and unfettered expediency. ${ }^{70}$ The liberty interests protected by the Fourth Amendment, for example, are protected against expediency arguments as a matter of constitutional principle. Stevens argues for a traditional way of viewing liberty interests; he derives support for his position from his ability to see and to describe the value of the liberty interests at stake in this particular case, and their connection with human individuality.

\section{B. Carr v Allison Gas Turbine Division, General Motors Corp ${ }^{71}$}

Mary Carr was the first woman to work in the tinsmith shop of the gas turbine division of General Motors's plant in Indiana. ${ }^{72}$ Over a period of five years, she encountered sexual harassment from her male coworkers. During four of the five years, she complained to her supervisor, to no avail. ${ }^{73}$ In 1989 , she decided that the situation had become unbearable and quit. She brought suit against General Motors ("GM"), seeking back pay and other relief. After a bench trial, District Judge Larry J. McKinney ruled in favor of GM, accepting the company's arguments that the alleged harassment was merely sexual bantering of a type common in the workplace and that GM was powerless to stop this bantering. ${ }^{74}$ On appeal, the Seventh Circuit ruled in favor of Mary Carr in an opinion written by Judge Richard Posner.

This case is unusual because the appellate court overruled the trial court's findings of fact. At the opening of the opinion, Posner remarks that Carr's lawyers, concerned that the prevalent clear-error standard would make such a result unlikely, attempted to persuade the Court that there had been legal error in the lower court's opinion. ${ }^{75}$ Posner found no legal error, but he did find error in the findings of fact. The clear-error standard, he

\footnotetext{
70 This understanding of constitutional principle is not universally endorsed. It is, for example, fundamentally at odds with Judge Posner's economic approach to constitutional reasoning, according to which these liberty interests would in fact become a matter of expediency. Richard A. Posner, The Economics of Justice 231-407 (Harvard, 1983). Posner himself has more recently granted that liberty interests protected in the constitution cannot be fully explained on his economic model. Richard A. Posner, Sex and Reason 8 (Harvard, 1992); Richard A. Posner, Overcoming Law 553 (Harvard, 1995).

${ }^{71} 32$ F3d 1007 (7th Cir 1994).

${ }^{72}$ Id at 1009.

${ }^{73} \mathrm{Id}$ at 1010.

${ }^{74}$ Id at 1008-10.

${ }^{75} \mathrm{Id}$ at 1008.
} 
wrote, "requires us appellate judges to distinguish between the situation in which we think that if we had been the trier of fact we would have decided the case differently and the situation in which we are firmly convinced that we would have done so."76 Posner thus announced at the start that his ruling was based on this sort of firm conviction. His account of the facts must therefore support that judgment.

When we speak of "facts" in this case, we must be aware that these are not "facts" as distinct from values and evaluation. There is no dispute about the incidents that occurred in the tinsmith's shop. What is in dispute is their human meaning-how intimidating they were, how adversely they affected the climate in which Carr worked. The relevant facts, then, are human facts of the sort the literary judge is well equipped to ascertain. The questions before Posner, he said, were two: "whether the plaintiff was, because of her sex, subjected to such hostile, intimidating, or degrading behavior, verbal or nonverbal, as to affect adversely the conditions under which she worked"; and "whether, if so, the defendant's response or lack thereof to its employees' behavior was negligent." ${ }^{\prime 77}$ We should note that the relevance of these questions is determined by Title VII, ${ }^{78}$ and not by Posner's untethered imagining. If there had been no law authorizing him to look for human facts of this nature, he would have had no basis for everything that follows. On the other hand, Title VII, as written, clearly needs supplementation by the judge, who must ascertain human facts of this type. ${ }^{79}$ We may expect, in other words, that to resolve such questions of "fact" will require a good deal of "fancy."

After giving his view of the technical issue of clear-error and after articulating the questions to be asked about the facts, Posner then told Mary Carr's story:

Carr was a drill operator in GM's gas turbine division when, in August 1984, she entered the skilled trades in the division as a tinsmith apprentice. She was the first woman to work in the tinsmith shop, and her male coworkers were unhappy about working with a woman. They made derogato-

$76 \mathrm{Id}$

77 Id at 1008-09. A third question raised by the district judge- "whether it was unwelcome harassment"-was dismissed by Posner as a nonquestion: "Welcome sexual harassment' is an oxymoron ...." Id at 1008.

78 Title VII, Civil Rights Act of 1964, 42 USC $\$ \S 2000$ e et seq (1988 \& Supp 1993).

79 Id. 
ry comments of a sexual character to her on a daily basis (such as, "I won't work with any cunt"), continually referred to her in her presence by such terms as "whore," "cunt," and "split tail," painted "cunt" on her toolbox, and played various sex- or gender-related pranks on her, such as painting her tool box pink and (without her knowledge) cutting out the seat of her overalls. They festooned her tool box and work area with signs, pictures, and graffiti of an offensive sexual character, hid and stole her tools, hid her toolbox, hung nude pin-ups around the shop, and would strip to their underwear in front of her when changing into and out of their work clothes. One of them placed an obscene Valentine Day's card, addressed to "Cunt," on her toolbox. The card shows a man carrying a naked woman upside down, and the text explains that the man has finally discovered why a woman has two holes-so that she can be carried like a sixpack. A worker named Beckham twice exhibited his penis. The first time, during an argument in which Carr told him the exit door "swings both ways," meaning that he could leave just as easily as she could, he replied that he had something that "swings," and he demonstrated. The second time, another male worker bet Beckham $\$ 5$ that he would not expose himself. $\mathrm{He}$ lost the bet, although it is unclear whether Carr was in front of Beckham or behind him. And it was Beckham who told Carr on another occasion that if he fell from a dangerous height in the shop she would have to give him "mouth to dick" resuscitation. Carr's male coworkers urinated from the roof of the shop in her presence, and, in her hearing, one of them accused a black employee who was only intermittently hostile to Carr of being "after that white pussy, that is why you want a woman here, you want some of that." A number of racist remarks and practical jokes of a racial nature were directed against this, the only black employee among the tinsmiths. A frequent remark heard around the shop was, "I'll never retire from this tinsmith position because it would make an opening for a nigger or a woman." Another of Carr's male coworkers threw a burning cigarette at her. ${ }^{80}$

Carr began complaining to her immediate supervisor, Jim Routh, 
[t]o no avail. He testified that even though some of the offensive statements were made in his presence, not being a woman himself he was not sure that the statements would be considered offensive by a woman. His perplexity was such that when he heard the statements he would just chuckle and bite down harder on his pipe. ${ }^{81}$

This description is in one sense straightforward, but it manifests considerable literary selectivity and skill. Posner positions himself close to the scene-he narrates the facts in more detail than would have been strictly necessary. And yet his stance is that of a judicious observer whose attitude to the conduct of the male workers is highly critical. The sardonic use of words such as "festooned," and "the text explains," his insistence on the both offensive and threatening character of the workers' behavior to Carr, and especially his vivid satirical portrait of Routh ("his perplexity was such ...") tell us that he sees through the argument, made by GM throughout, that all this was merely a kind of joking or prank-playing in which workers of both sexes engaged. He positions himself as someone who (unlike Routh) can imagine the likely impact of this conduct on a female employee. As I shall argue later, being satirical and highly critical can be a part of being judicious. When discussing Carr's difficult personal situation-her foster son was executed for murder-Posner took the opportunity to mention that "one of the charming comments that Beckham, the coworker who had exposed himself to her, had made to her was that he would have been happy to pay the electrical bill for the execution."

Posner then confronted the question of impact directly, addressing himself to the district judge's contention that the tinsmiths' behavior was not harassment because offensive language is common in the workplace and that employers are under no legal obligation to purify the workplace of this language just because some find it offensive. We must, Posner held, insist on the difference between the "merely vulgar and mildly offensive" and the "deeply offensive and sexually harassing." ${ }^{\text {" } 30}$ attempted to articulate that distinction by considering Carr's situation:

For one thing, the words and acts of which she complains were, unlike what may have been the situation in [another 
relevant case], targeted on her, and it is a lot more uncomfortable to be the target of offensive words and conduct than to be merely an observer of them. Patricia J. Williams, The Alchemy of Race and Rights: Diary of a Law Professor 129 ([Harvard,] 1991). For another thing, defacing a person's property (even if it is hers just to use while at work) and mutilating her clothing (even if it is hers just to wear while at work) are more ominous, more aggressive affronts than mere words. ${ }^{84}$

Here we see a use of empathy in connection with judicious assessment. It is interesting that Posner, who is well-known for using many fewer citations and footnotes than most judges, and who is personally responsible for the citations in his opinions, cites the work of a legal scholar, Patricia Williams, on race as a source for his conclusions in this paragraph. He seems to be suggesting that his complete assessment of Carr's contention required comparison with other narratives from people in relevantly similar positions of social inequality.$^{85} \mathrm{It}$ was perhaps not easy for a judge in Posner's position to answer, solely on the basis of his own judgment and experience, the question of whether the intimidation Carr reportedly felt was reasonably based in the objective facts of her situation. Part of his solution was to consider other stories of harassment. Viewed as a deliberately chosen literary device, the Williams reference demonstrates a determination to try to get close to the experience of people in positions of inequality, as if that were a factor relevant to the correct resolution of the factual question before him.

Posner next turned to the district judge's contention that the behavior, though harassing, was not unwelcome to Carr, who herself used words like "fuck head" and "dick head," once placed her hand on the thigh of a male coworker, and, "when shown a pornographic picture and asked to point out the clitoris, obliged." ${ }^{86}$ She provoked misconduct, in short, because she was "unladylike," to use the district judge's word. Posner commented:

Even if we ignore the question why "unladylike" behavior should provoke not a vulgar response but a hostile, harass-

${ }_{84}$ Id.

85 Posner had already made the connection between sexual and racial harassment in his description of the tinsmiths' treatment of a black coworker who refused to join fully in the anti-Carr campaign. Id.

86 Id. 
ing response, and even if Carr's testimony that she talked and acted as she did in an effort to be "one of the boys" is (despite its plausibility) discounted, her words and conduct cannot be compared to those of the men and used to justify their conduct and exonerate their employer. ... The asymmetry of positions must be considered. She was one woman; they were many men. Her use of terms like "fuck head" could not be deeply threatening, or her placing a hand on the thigh of one of her macho coworkers intimidating; and it was not she who brought the pornographic picture to the "anatomy lesson." We have trouble imagining a situation in which male factory workers sexually harass a lone woman in self-defense as it were; yet that at root is General Motors' characterization of what happened here. ${ }^{87}$

This is a calm and entirely unsentimental paragraph. Posner is not wringing his hands or emoting in the manner of one personally caught up in the situation. In all respects he is the judicious spectator, and he does seem to fulfill Smith's conception of that quasi-literary role. His test is, in effect, one of "fancy": Try to imagine the situation as the male workers describe it, in which Carr was just as threatening to them as they to her, and you find you can't do it. (Note the italicization of "imagining.") But picture the asymmetry of the situation as it was, picture her isolation and her lack of support from the supervisor, and you come to the conclusion that she was the victim of a campaign of harassment of remarkable duration and intensity.

Did GM act improperly? Posner held that negligence was proved, despite the district judge's determination that GM was the victim of "a conspiracy of silence among the tinsmiths"-a phrase that leaves the reader in no doubt of Posner's critical response. ${ }^{88} \mathrm{He}$ concluded, "We do not find the picture of mighty GM helpless in the face of the foul-mouthed tinsmiths remotely plausible ...." ${ }^{\prime 89}$ Here, once again, appeal to the imagination yields the judicious spectator's sardonic response. Posner then commented, with respect to Carr's situation, that to obtain "a remedy for constructive discharge" she needed show simply "that the discrimination to which she was subjected was sufficiently serious to cause a reasonable person to quit"-a traditional com-

\footnotetext{
87 Id at 1011 (citations omitted).

Id at 1012.

$\varepsilon$ Id.
} 
mon law standard that in effect incorporates the responses of Smith's judicious spectator into the resolution of the case. ${ }^{90}$

We now arrive at Posner's conclusion:

It is difficult for an employer to sort out charges and countercharges of sexual harassment among feuding employees, but we are dealing here with a situation in which for years one of the nation's largest enterprises found itself helpless to respond effectively to an egregious campaign of sexual harassment directed at one woman. No reasonable person could imagine that General Motors was genuinely helpless, that it did all it reasonably could have done. The evidence is plain that it (or at least its gas turbine division) was unprepared to deal with problems of sexual harassment even when those problems were rubbed in its face, and also incapable of improvising a solution. Its efforts at investigation were lackluster, its disciplinary efforts nonexistent, its remedial efforts perfunctory. The U.S. Navy has been able to integrate women into the crews of warships; General Motors should have been able to integrate one woman into a tinsmith shop.

The judgment is reversed with instructions to enter judgment on liability for the plaintiff (since no other result would be consistent with the record ... ) and proceed to a determination of the remedy to which she is entitled. ${ }^{91}$

Posner thus concluded with a direct appeal to the imaginings and responses of a reasonable person-or a judicious spectator. $\mathrm{He}$ shows in his prose the well-founded indignation and contempt that such a spectator feels at the behavior of GM. In literary terms, the paragraph seems to refer to traditional devices and emotions of the genre of satire, whether in its ancient Roman form (Juvenal) or in more recent exemplars such as the works of Swift. ${ }^{92} \mathrm{He}$ denounces the pretense that GM was helpless and expresses his view of both GM and the tinsmiths in the metaphorical "even when those problems were rubbed in its face"-comparing GM to an incontinent dog. The rhetorically effective sentence beginning "Its efforts" expresses indignation in a tricolon of ascending condemnation; the next sentence uses the

90 Id at 1011-12.

91 Id at 1012-13 (citations omitted).

92 The saeva indignatio mentioned in Swifts epitaph is, perhaps, the emotion Posner's prose is attempting to construct. 
phrase "been able to integrate" to bring home the parallel between the task faced (and accomplished) by the Navy and the task refused by GM.

Posner carefully positions himself as a spectator, detached and neutral in the appropriate ways. But imagination and appropriate emotion are crucial in the reasoning of his opinion. His indignation is not capricious: it is solidly grounded in the facts, and he can make his reader feel it in his narration of those facts. Indeed, his opinion does what good satire of the Juvenalian or Swiftean kind does: it inspires indignation through the mordant and factually convincing portrayal of human venality and cruelty. Here, as in the Stevens opinion, the literary approach is closely connected with sympathetic attention to the special plight of people who are socially unequal. Posner repeatedly draws attention to this aspect of his thinking, and to its relevance in answering the legal questions about intimidation and hostility. As Posner writes: "The asymmetry of positions must be considered."

\section{Bowers v Hardwick ${ }^{93}$}

Both the case and the opinions are famous; I shall therefore do less summarizing than in the other cases. But let us set the stage briefly. ${ }^{94}$ Michael Hardwick was in a bedroom in his apartment, engaged in fellatio with another man, when he was arrested by a police officer who had entered the apartment to serve an arrest warrant on Hardwick for drinking in public. Both men were arrested for violating Georgia's sodomy law, held in jail for ten hours, and released without charges being lodged against them. Hardwick brought a suit to invalidate the law. ${ }^{95}$ The law itself was worded in terms of sexual acts, defining sodomy as either oral or anal intercourse. ${ }^{96}$ As is frequently the case in sodomy statutes, the offense was not restricted to homosexuals, and a heterosexual couple known as John and Mary Doe later joined the suit, though their case never reached the Supreme Court. ${ }^{97}$ The district court held that they "had neither sustained,

\footnotetext{
93478 US 186 (1986). This Section will focus on the opinions by Justice White and Chief Justice Burger.

*4 The Supreme Court opinions in Hardwick provide only a minimal account of the circumstances surrounding the arrest of Michael Hardwick. See id at 187-88. For a fuller version, see Note, Chipping Away at Bowers v. Hardwick: Making the Best of an Unfortunate Decision, 63 NYU L Rev 154, 159 (1988).

${ }_{95}$ Note, 63 NYU L Rev at 159-60.

${ }^{96}$ Hardwick, 478 US at $188 \mathrm{n} 1$.

${ }^{97}$ Id at $188 \mathrm{n} 2$.
} 
nor were in any immediate danger of sustaining, any direct injury from the enforcement of the statute," and the appellate court affirmed the district court's judgment, dismissing the Does' claim for lack of standing. ${ }^{98}$ In this way the record virtually acknowledged that the statute was not enforced against heterosexuals.

The majority and concurring opinions in Hardwick have been criticized often and from many different points of view. To assess the literary or nonliterary aspects of the opinions, we must first consider the case as it was actually argued-as a due process challenge. We can then ask how aspects of the literary imagination would prove relevant to arguing this or a similar case under the Equal Protection Clause-a line of argument suggested in Justice Blackmun's dissent ${ }^{99}$ and in recent legal scholarship on the topic. ${ }^{100}$

The question before the Court was whether the alleged right to consensual homosexual sodomy was in fact conferred by the Constitution. The Court noted that the category of rights in question has been identified as including "those fundamental liberties that are "implicit in the concept of ordered liberty" and those that are "deeply rooted in this Nation's history and tradition." 101 It is important to note these constraints on the result and the reasoning in the case. Any sympathy or imagination is irrelevant unless it bears either on the connection between this case and relevant precedents or on the question whether the case fits one or both of the two general descriptions deriving from earlier cases.

Concerning the precedents, Justice White reviewed the privacy cases and found

that none of the rights announced in those cases bears any resemblance to the claimed constitutional right of homosexuals to engage in acts of sodomy that is asserted in this case. No connection between family, marriage, or procreation on

98 Hardwick $v$ Bowers, 760 F2d 1202, 1206-07 (11th Cir 1985). Posner discusses a peculiarity of the situation in his excellent treatment of the case in Sex and Reason at 341-50 (cited in note 70). At common law, sodomy did not include fellatio, but was limited to anal intercourse; the extension took place late in the nineteenth century. Id at 343 .

99478 US at 201-02 (Blackmun dissenting).

100 See, for example, Posner, Sex and Reason at 348-49 (cited in note 70); Cass R. Sunstein, Sexual Orientation and the Constitution: $A$ Note on the Relationship Between Due Process and Equal Protection, 55 U Chi L Rev 1161, 1179 (1988).

${ }^{101}$ Hardwick, 478 US at 191-92, quoting Palko $v$ Connecticut, 302 US 319, 325-26 (1937). 
the one hand and homosexual activity on the other has been demonstrated .... Moreover, any claim that these cases nevertheless stand for the proposition that any kind of private sexual conduct between consenting adults is constitutionally insulated from state proscription is unsupportable. ${ }^{102}$

This reading of the privacy cases is certainly plausible. It is indeed true that Griswold $v$ Connecticut focused on decisional privacy in the context of the marital relationship and with reference to decisions about childbearing. ${ }^{103}$ Although Eisenstadt $v$ Baird extended this right to unmarried individuals, and thus recognized a decisional privacy right of individuals rather than couples, it still focused on decisions involving whether or not to bear a child. ${ }^{104}$ Eisenstadt held that "[i]f the right of privacy means anything, it is the right of the individual, married or single, to be free from unwarranted governmental intrusion into matters so fundamentally affecting a person as the decision whether to bear or beget a child." 105 This wording suggests that there might be other fundamental person-affecting rights in this area. But no other rights are named; and since Eisenstadt was tried as an equal protection case, its central line of argument was simply that whatever contraceptive rights married people have must belong to the unmarried as well. Roe $v$ Wade, which famously discussed a woman's right to terminate her pregnancy, also recognized a decisional right of privacy for individuals, but also focused on the decision whether to have a child. ${ }^{106}$ The step from Eisenstadt and Roe to the acknowledgment of a right of consenting adults to engage in the sexual conduct of their choice is not long. ${ }^{107}$ But one must grant that this step had not yet been taken. ${ }^{108}$

What could the relevance of literary imagining possibly have been to the determination whether this step should have been taken? What we find in the previous privacy cases is a consider-

102 Hardwick, 478 US at 190-91.

103381 US 479 (1965).

104405 US 438 (1972).

105 Id at 453.

100410 US 113 (1973).

${ }^{107}$ See Posner, Sex and Reason at 342 (cited in note 70) ("Had he [Justice White] noted that besides being about family, marriage, and procreation, [these cases] had been about sex, he could not have polished them off so easily.").

${ }^{103}$ See Thomas C. Grey, Eros, Civilization, and the Burger Court, 43 L \& Contemp Probs 83 (Summer 1980). 
ation of the way in which the recognized privacy rights shield liberties of personal choice in intimate matters that fundamentally affect one's personhood. Given the vagueness about the range of this protection, we might expect therefore that a thorough sifting of the question involved in Hardwick would also involve a close consideration of the person-affecting character of the privacy right claimed by Hardwick. The majority opinion, however, maintains a lofty distance from the facts of Michael Hardwick's situation. ${ }^{109}$ The distancing language ("the claimed constitutional right of homosexuals to engage in acts of sodomy"110) expresses a refusal to think about how Hardwick's personhood is affected by the issue and even seems to express a somewhat sardonic attitude toward his suggestion that the right involved deserves protection. Indeed, throughout the opinion there seems to be a marked effort to keep the human story at a distance, not to describe the events as if they happened to someone one might know-or even be. A more empathetic consideration of the situation of someone whose chosen form of consensual sexual conduct is illegal might not have changed the judgment about how to read the precedents, but it would have promoted a full and thorough consideration of the question of the reach of the privacy right. Such a thorough consideration does not seem to have taken place here, so rapidly is Hardwick's contention dismissed.

Indeed, we may note that the relationship of this case to fundamental issues of personhood receives far less discussion than took place in a far more trivial case. In Kelley $v$ Johnson, the Court considered a police department regulation limiting the length of policemen's hair. ${ }^{111}$ This was occasion for a substantial discussion, albeit in the dissent, of the relationship of personal appearance to integrity and personal identity, and of all of these to the privacy right. ${ }^{112}$ Surely Hardwick's case, in addition to its greater human urgency, lay far closer to the precedents and involved a right that could, with far more plausibility, have been connected to them.

If we turn to the next question, whether the alleged right fits one or both of the two relevant general descriptions, we find again, in both the majority and the concurring opinions, a de-

\footnotetext{
109 For a related example in another opinion by Justice White, see Richard A. Posner, Law and Literature: A Misunderstood Relation 309 (Harvard, 1988), referring to Cox Broadcasting Corp $v$ Cohn, 420 US 469 (1975).

110 Hardwick, 478 US at 190-91.

111425 US 238 (1976).

112 Id at 249-61 (Marshall dissenting).
} 
tached and markedly non-narrative approach. "Proscriptions against that conduct have ancient roots," wrote the majority, who then simply dismissed the idea that a right to commit homosexual sodomy is either "implicit in the concept of ordered liberty" or "deeply rooted in this Nation's history and tradition." Justice Burger's concurring opinion was even more severe. Burger stated that "[d]ecisions of individuals relating to homosexual conduct have been subject to state intervention throughout the history of Western civilization." ${ }^{\text {"14 }}$ He noted that

Blackstone described "the infamous crime against nature" as an offense of "deeper malignity" than rape, a heinous act "the very mention of which is a disgrace to human nature," and "a crime not fit to be named." . . To hold that the act of homosexual sodomy is somehow protected as a fundamental right would be to cast aside millennia of moral teaching. ${ }^{115}$

The severity of Burger's language, as well as his lengthy enumeration of such historical condemnations, serves to distance both the Court and the reader even further from the perspective and story of Michael Hardwick himself, a human being seeking to live a fully human life. Burger encourages us to see Hardwick as a dangerous criminal, similar to a rapist, and nothing in the way the facts of his story are related informs us otherwise.

Closely connected to this distancing strategy, I believe, is the fact that we find in the opinions no argument concerning the question of what level of generality the Court should use in this case. Described at a highly specific level as "a right to commit homosexual sodomy," the right in question is not traditional, and it has not been traditionally considered to be implicit in the concept of ordered liberty. On the other hand, were the right in question understood generally, as a right to determine the course of one's own sexual life so long as one does not harm others, it could at least be argued that such a right was recognized in a variety of previous cases, for example those involving the right to marry a partner of one's choice. Indeed, the dissents so argue, connecting sodomy laws to laws forbidding miscegenation. ${ }^{116}$ After all, miscegenation, described concretely as "marriage to a partner of a different race," was of course not a traditionally

\footnotetext{
${ }^{213}$ Hardwick, 478 US at 191-92.

114 Id at 196 (Burger concurring).

115 Id at 197.

${ }^{116}$ See, for example, id at 216 n 9 (Stevens dissenting).
} 
recognized fundamental right. Described generally, however, as "marriage to a partner of one's choice," it does involve such a right. But there the majority in Hardwick make no attempt to discuss this vital issue of generality, so evident does it seem to them that homosexual sex is unrelated to other liberty interests in the area of sex and marriage. This avoidance of argument is facilitated by treating the homosexual like an evil pariah, whom centuries of history have concurred in condemning. If it seemed to Blackstone disgraceful even to mention such acts, it is easy to justify not dwelling on them very long in thought and argument as might be necessary to work out properly their relationship to other acts.

What would one expect from the literary imagination here, and what relevance might it have? One would expect, I think, two things that were sorely lacking in the majority and concurring opinions: a careful attention to history and social context, and an empathetic consideration of the situation of the homosexual in American society. History first. The historical claims made in the opinions are imprecise and, to a great extent, false. Study of the history of sexual conceptions and practices is a burgeoning area of scholarship in many fields of the humanities and social sciences. Books that are not at all beyond the reach of the nonspecialist have by now exploded the simple picture of a history of condemnation on which the majority relies, whether in the GrecoRoman, Christian, Jewish, or English traditions. ${ }^{117}$ The literary judge would wish to "read" Michael Hardwick's case in its full historical and social context, which would entail getting the history right, if it was appealed to at all.

Getting the history right might or might not affect the result-for one could still argue that the right level on which to define the relevant rights was the most specific level and that the

${ }^{117}$ See K.J. Dover, Greek Homosexuality (Harvard, 1978); Martha C. Nussbaum, Platonic Love and Colorado Law: The Relevance of Ancient Greek Norms to Modern Sexual Controversies, 80 Va L Rev 1515 (1994) (discussing the historical evidence and its relevance to contemporary law and including as an appendix a statement coauthored by Nussbaum and Dover, in which Dover makes some important corrections to the view of Plato he put forward in Greek Homosexuality, and also makes his position on the contemporary issue plain). See also Kenneth Dover, Marginal Comment: a memoir (Duckworth, 1994) (autobiography). On the Christian Tradition, see John Boswell, Christianity, Social Tolerance and Homosexuality: Gay People in Western Europe from the Beginning of the Christian Era to the Fourteenth Century (Chicago, 1990); and on the prohibitions of Leviticus, see Saul Olyan, "And With a Male You Shall Not Lie the Lying Down of a Woman": On the Meaning and Significance of Leviticus 18:22 and 20:13, 5 J Hist Sexuality 179 (1994). 
relevant Anglo-American legal traditions would not uphold the classification of the right in question, specifically defined, as "implicit in the concept of ordered liberty" or "deeply rooted in this Nation's history and tradition." But understanding how other times and places have viewed similar conduct would have provided a much-needed basis for considering the possible relevance of a more general level of description. Similarly, considering in an empathetic manner what was actually at stake for Hardwick in the case might also have led the Court to evaluate the right at a higher level of generality. Such empathetic consideration-of which Forster's Maurice gives us one vivid example-would at least have raised, if not settled, the question of the relationship between this right and the traditionally protected rights to marry and to control one's own reproductive choices.

In these ways, the literary element in judging might have contributed to a fuller deliberation about aspects of the case, even as it was actually argued under the Due Process Clause. Had the case been argued under the Equal Protection Clause, the relevance of empathetic imagination would have been clearer still. And although the Hardwick decision blocked the due process route, similar cases might still be argued by appeal to equal protection. Indeed, Justice Blackmun in dissent recognized that the case has a serious equal protection aspect, and might have been argued in this way. ${ }^{118}$ More recently, Cass Sunstein has argued that the equal protection route would have been preferable in the case because, in his view, the Due Process Clause is typically backward-looking and tradition-respecting, while the Equal Protection Clause is forward-looking and reform-oriented. ${ }^{119}$ An equal protection argument typically requires consideration of the history of discrimination under which a group has labored, as well as its circumstances of political powerlessness. ${ }^{120}$ Richly detailed, empathetic, and historically concrete consideration would have sufficed to reveal a history of discrimination that exposes the parallels between this case and other histories of the persecution of marginalized and despised groups. Indeed, it would appear that this sort of inquiry is not only sufficient for that understanding, but necessary as well-for without it, it is difficult to make the all-important distinction between Michael Hardwick's situation and that of a violent crimi-

11 Hardwick, 478 US at 202 (Blackmun dissenting).

119 Sunstein, 55 U Chi L Rev at 1163 (cited in note 100).

122 Id. 
nal (Blackstone's rapist mentioned by Burger) whose acts are subject to penalty for very good reasons. In order to think well about an equal protection argument, we have to be able to separate irrational discrimination from condemnation of what is genuinely dangerous. An understanding of the history of the prejudice against homosexuals in American society, combined with awareness of different attitudes in other cultures and with a sympathetic understanding of the aims and intentions of actual homosexuals, would, I believe, show that this group is relevantly similar to racial minorities, women, and national minorities, rather than to rapists or to child molesters. It would be difficult to get to this result without using the imagination, especially when the majority and concurring opinions treat homosexuals with such repugnance and distance.

The constitutional issues bearing on this case are highly complex, and are disputed at every point. A judge deciding such a case is constrained in many ways by text, history, and specific precedent. It would be foolish to claim that the literary imagination does all the work here, and inappropriate to recommend that it work outside these institutional constraints. On the other hand, within these constraints it can supply insights that should prove valuable to a complete deliberation on the relevant issues.

Does literary judging make a difference? Certainly not in all imaginable cases. Sometimes the legal issues tell clearly one way or another; sometimes the facts are so simple and uncontroversial that literary imagining is not important. In all cases, the law must first of all be there, or no judge can do anything. Justice Stevens's interest in Palmer's photos and letters goes nowhere without the text of the Constitution, a range of specific precedents, and the admission by the majority itself that merely malicious and harassing searches are intolerable. Judge Posner would have been powerless to rule on behalf of Mary Carr without Title VII, however much he abhorred sexual harassment. Legislators too, and the citizens who elect them, need to exercise imagination. The notorious difficulties surrounding the scope and the very existence of the privacy right show how difficult it is for judges to rule innovatively, even to plug what might seem a gap in the text of the Constitution. Empathetic citizens should not rely on the judiciary alone to require what they think just.

But in these three cases-two of which involve highly contested constitutional questions and the third of which involves a deep disagreement about how to assess the facts-the full, precise, and judicious imagining of the human facts did, or at least 
might, make at least some difference in the result: in Hudson, by giving Stevens a sense of the importance for Palmer of the property interest Hudson had maliciously violated; in Carr, by giving Posner a vivid sense of the harassment suffered by Carr and of the implausibility of GM's version of the facts; in Hardwick as actually argued, possibly, by giving the hypothetical literary judge a sense of the fundamental nature of the rights and liberties involved and their relation to other fundamental liberties; in Hardwick seen as an equal protection case, by giving the judge an understanding of the special disadvantages faced by gay and lesbian people, of the history of sodomy laws as instruments of discrimination, of the general social stigma associated with being the target of such laws. Moreover, even where the result is not affected, an opinion, addressed to other judges, may well alter their ways of perceiving an issue, and may thus affect judicial practice indirectly.

In none of the cases do I suggest that technical legal reasoning, including prominently the consideration of precedent, should be subordinated to untethered sentiment. The judge is not a legislator, and his imagination must conform to tight institutional constraints. In the Carr and Hudson opinions, the sentiments of sympathy and indignation that are expressed are valuable precisely because they are connected to good legal reasoning of a traditional sort and to a solid grasp of the facts. As I have said, Posner's imagination was given some (albeit unspecific) instructions and limits by Title VII. But in both cases we can say, I think, that the literary judge has a better grasp of the totality of the facts than the non-literary judge. My claim is, then, that literary judging is by no means sufficient for good judging, and could certainly be pernicious if not properly tethered to other purely institutional and legal virtues; but, whatever else we demand, we should demand this type of judging in appropriate circumstances.

\section{ATTESTING SYMPATHY}

I now return to Whitman. For I have now come round to several themes that lie at the heart of Whitman's poetry: the pain of social exclusion, the relationship between the exclusion of the homosexual and other exclusions based on gender and religion and race, the interest all citizens have in liberty, erotic and otherwise, the importance of fostering a political rationality that can "see into" that interest. I have suggested, with Whitman, that a literary imagining of the importance of various liberty and 
equality interests for citizens offers valuable guidance in cases dealing with those interests. So I shall conclude by discussing a section of Whitman's Song of Myself in which all these themes are brought together. The passage comes about halfway through the poem, after a section (10) in which the poet-speaker houses a runaway slave, tending the sores left by the irons on his legs and ankles, ${ }^{121}$ and after the parable "Twenty-eight young men bathe by the shore," a vivid lyrical depiction of the exclusion of the female from full inclusion and equality as a sexual being. ${ }^{122}$ "I am he attesting sympathy," summarizes the poet. ${ }^{123}$ He now announces that in and through his imagination the excluded find speech and their emotions find recognition:

Unscrew the locks from the doors!

Unscrew the doors themselves from their jambs!

Whoever degrades another degrades me,

And whatever is done or said returns at last to me...

I speak the pass-word primeval, I give the sign of democracy,

By God! I will accept nothing which all cannot have their counterpart of on the same terms.

Through me many long dumb voices,

Voices of the interminable generations of prisoners and slaves,

Voices of the diseas'd and despairing and of thieves and dwarfs,

Voices of cycles of preparation and accretion,

And of the threads that connect the stars, and of wombs and of the father-stuff,

And of the rights of them the others are down upon,

Of the deform'd, trivial, flat, foolish, despised,

Fog in the air, beetles rolling balls of dung.

Through me forbidden voices,

Voices of sexes and lusts, voices veil'd and I remove the veil,

Voices indecent by me clarified and transfigur'd. . . .

Dazzling and tremendous how quick the sun-rise would kill me,

If I could not now and always send sun-rise out of me. ${ }^{124}$

121 Walt Whitman, Song of Myself lines 189-94, in Walt Whitman, Leaves of Grass 28, 38 (cited in note 2 ).

122 Id lines 199-216 at 38-39.

${ }^{123}$ Id line 461 at 50 .

124 Id lines 501-04, 506-18, 560-61 at 52-54. 
The poet's democratizing mission is one of imagination, inclusion, sympathy, and voice. The poet is the instrument through which the "long dumb voices" of the excluded come forth from under their veils and into the light. To attend to the way things are with the excluded and the despised as well as the powerful, to insist on participating oneself, through sympathy, in the degradation of the degraded, to give voice to the pain of the excluded, the intimidation of the harassed-this is a norm of democratic judgment highly pertinent to the situation of Bigger Thomas, of Forster's Maurice, of Mary Carr, of the prisoner Palmer, of Michael Hardwick. Whitman claims that the light of the poetic imagination is a crucial agent of democratic equality for excluded people, since only that imagination will get the facts of their lives right and see in their unequal treatment a degradation of oneself.

I claim that it would be a good thing to have judges who could see into those lines. The sympathy of the judicious spectator does not by itself dictate any specific result in any particular legal case. It is constrained in many ways by statute and precedent. Nor, even as imagination, does it stand alone. It needs to be able to rely on imagination and compassion already exercised in the legislative sphere. But it does exemplify a type of thinking that should be involved in judicial reflection. In order to be fully rational a judge must be capable of literary imagining and sympathy. She must educate not only her technical capacities but also her capacity for humanity. This means, I think, that literary art is an essential part of the formation of the judge-and, more generally, of the formation of citizenship and public life. 
,

$\therefore$ 